\title{
Kivennäismaan kasvukauden aikaiset vesipitoisuusmuutokset ja niiden paikallinen pysyvyys
}

\author{
Pekka Hänninen ${ }^{1}$, Antti Ristolainen ${ }^{2}$ ja Laura Alakukku ${ }^{3}$,

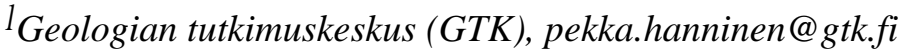 \\ ${ }^{2}$ Maa- ja elintarviketalouden tutkimuskeskus (MTT), antti.ristolainen@mtt.fi \\ ${ }^{3}$ Helsingin yliopisto (HY), laura.alakukku@helsinki.fi
}

\section{Tiivistelmä}

Maa- ja elintarviketeollisuuden (MTT), Geologian tutkimuskeskuksen (GTK) ja Helsingin yliopiston (HY) yhteisissä hankkeissa Maaperäfysiikka ja sato I ja II tutkittiin peltomaan geofysikaalisten ominaisuuksien paikallista ja ajallista vaihtelua. Hankkeiden yhtenä tavoitteena oli selvittää, voidaanko lohkon maan vesipitoisuuden muutosta ennustaa yhden jatkuvatoimisen mittauspisteen tulosten perusteella, kun lohkon ominaisuuksien alueellinen jakauma tunnetaan.

Hankkeissa perustettiin neljälle koealalle kiinteä mittausasema, jossa seurattiin jatkuvatoimisesti kolmen vuoden ajan maaperän lämpötilaa, vesipitoisuutta ja sähkönjohtavuutta 30, 60 ja 90 senttimetrin syvyydessä. Kaksi mittausasemaa oli savipellolla (Jokioinen ja Vihti), yksi hietapellolla (Hausjärvi) ja yksi moreenipellolla (Juva). Savipelloilla seurattiin lisäksi salaojakaivon veden sähkönjohtavuutta ja lämpötilaa. Mittaustiheys oli kolme tuntia. Edellä mainittujen asemien lisäksi tutkimuksen tausta-aineistona käytettiin Ylistarossa olevaa, vanhalle peltoalueella perustettua, GTK:n maaperän lämpötila ja vesipitoisuusseuranta-aseman tuloksia. Peltoalueiden sähköiset ominaisuudet mitattiin kolme kertaa kasvukauden aikana 10*10 m mittausverkossa.

Seuranta-asemien mittausten perusteella havaittiin, että ruokamultakerroksen alapuolella maan kosteuden muutokset olivat suhteellisen pieniä. Kasvukaudella $75 \%$ kahden viikon aikana tapahtuneista maan kosteuden muutoksista oli pienempiä kuin 5 tilavuusprosenttiyksikköä. Voimakkaitten sateiden jälkeen peltomaassa voi tapahtua nopeasti suuria kosteuspitoisuuden muutoksia. Suurimmat maan kosteuden muutokset kahdessa viikossa havaittiin Jokioisten savipellolla, missä maa kuivui yhdessä prosentissa tapauksista 20 (30 cm:ssä) ja vettyi 22 (60 cm:ssä) tilavuusprosenttiyksikköä kahdessa viikossa. Kun yli $20 \mathrm{~mm}$ kesäsateet imeytyivät muokkauskerrosta syvemmälle, niiden vaikutukset voitiin havaita $30 \mathrm{~cm}: n$ syvyydessä $10-14$ vuorokauden ajan maalajista riippumatta.

Kenttämittausten perusteella maan kosteuden muutokset olivat spatiaalisesti pysyviä ja siten hallittavia yhden seuranta-aseman tulosten perusteella. Tutkimuksessa luotiin yksinkertainen malli, jossa jatkuvasti mittaavan seuranta-aseman ja keväällä tehdyn kertamittauksen perusteella kuvattiin kasvukauden aikana päivittäin peltoalueen vesitilaa ja sen muutosta.

Seurattujen makerrosten pääsääntöisesti lähes yhtaikaiset vesipitoisuusmuutokset osoittavat, että peltomaan veden liike riippuu pikemminkin oikovirtausreiteistä kuin maan materiaaliominaisuuksista.

Avainsanat :

Maan kosteus, dielektrisyys, geofysikaaliset mittaukset 


\section{Johdanto}

Täsmäviljely vaatii peltoalan maa-aineksen ja maan ominaisuuksien ja niiden vaihtelun tarkkaa tuntemusta. Peltoalueille on kehitetty ja kehitetään monen muuttujan malleja, joilla voidaan arvioida esimerkiksi maan vesipitoisuuden muutoksia. epäsuoraan maalajin, säätilan, kasvuston kehityksen yms. avulla. Geofysikaaliset suureet, kuten maaperän sähkönjohtavuus ja dielektrisyys, korreloivat useiden maan kasvukunnolle tärkeiden tekijöiden kanssa. Näiden sähköisten menetelmien avulla pystytään aluemittakaavassa luokittelemaan maaperää sekä sen ominaisuuksia. Vaikkakin maan, sään ja sadon vuorovaikutukset ovat paljon monimutkaisempia kuin mihin geofysikaalisilla mittauksilla voidaan vastata, antavat nämä epäsuorat mittaukset sellaista luokittelutietoa, jonka hankkiminen muilla menetelmillä on aikaa vievää ja kallista tuottaa.

Ollakseen käyttökelpoisia käytettävien mittausten on oltava alueellisesti pysyviä sekä alueiden mittaustulosten suhde toisiinsa ajallisesti toistettava. Lisäksi mitatuilla suureilla on oltava viljelyn kannalta mielekäs vaste. MTT:n, GTK:n ja HY:n yhteisissä hankkeissa 'Maaperäfysiikka ja sato (MaSa) 1 ja 2' tutkittiin, metsämaan luokittelussa käytettyjen, dielektrisyys ja sähkönjohtavuusmittauksien soveltuvuutta viljellyssä olleilla savi-, hiesu-, hieta- ja moreenipelloilla (Ristolainen ym., 2006, 2009). Metsämaan luokittelussa em. mittaukset olivat osoittautuneet paikan ja ajan suhteen riittävän stabiileiksi (Sutinen ym, 2007).

Koska maan sähköisten ominaisuuksien mittaaminen useita kertoja kasvukauden aikana on käytännössä mahdotonta, kullekin tutkimusalueelle perustettiin automaattinen seuranta-asema. Ajatuksena oli tutkia, voidaanko yhdellä havaintopisteellä ennustaa alueen sähköisten olosuhteiden muutosta, kun niiden alueellinen jakauma on tunnettu. Käytännössä seurattiin dielektrisyyden perusteella maan vesipitoisuuden muutosta sekä seuranta-asemien että toistettavien kenttämittausten perusteella.

\section{Aineisto ja menetelmät}

Koealueet valittiin siten, että niiden maalajit edustivat erityyppisiä peltoja (taulukko 1). Savisilla paikoilla maa-aineksen savipitoisuus oli lähes $80 \%$ ja niiden laskennallinen veden liikenopeus oli käytännöllisesti katsoen nolla. Karkeilla paikoilla kivennäisaines sisälsi vain $3 \%$ savea ja maa-aineksen laskennallinen liikenopeus oli noin metri vuorokaudessa.

Taulukko 1. Hausjärven, Jokioisten, Vihdin ja Juvan seuranta-asemien maanominaisuuksia. Veden liikenopeus laskettiin näytteiden perusteella Sauerbrein kaavan mukaan (Vukovic \& Soro, 1992). $\mathrm{d}_{50}$ : kivennäisaineksen raekoko $(\mu \mathrm{m})$, jota suurempia ja pienempi rakeita on $50 \%$.

\begin{tabular}{|l|c|c|c|c|c|c|}
\hline \multirow{2}{*}{$\begin{array}{l}\text { Koealue ja } \\
\text { mittaussyvyys } \\
(\mathrm{cm})\end{array}$} & \multicolumn{3}{|c|}{ Maan raekoko $(\mu \mathrm{m})$ ja sen jakauma (\%) } & \multicolumn{2}{c|}{$\begin{array}{c}\text { Maan } \\
\text { orgaaninen } \\
\text { hiili \% }\end{array}$} & $\begin{array}{c}\text { veden liike } \\
\mathrm{mm} / \mathrm{vrk}\end{array}$ \\
\cline { 2 - 5 } & $\leq 2$ & $2-60$ & $>60$ & $\mathrm{~d}_{50}$ & 3,4 & 15 \\
\hline Hausjärvi 30 & 12 & 29 & 59 & 80 & 0,4 & 2 \\
\hline Hausjärvi 60 & 19 & 35 & 46 & 40 & 1,5 & 0 \\
\hline Hausjärvi 90 & 60 & 37 & 3 & $<2$ & 4,2 & 0 \\
\hline Jokioinen 30 & 45 & 32 & 23 & 3 & 2,8 & 0 \\
\hline Jokioinen 60 & 39 & 40 & 21 & 5 & 0,9 & 0 \\
\hline Jokioinen 90 & 73 & 24 & 3 & $<2$ & 2,2 & 0 \\
\hline Vihti 30 & 49 & 43 & 8 & 2 & 0,6 & 0 \\
\hline Vihti 60 & 64 & 36 & 0 & $<2$ & 0,9 & 0 \\
\hline Vihti 90 & 78 & 22 & 0 & $<2$ & $?$ & 920 \\
\hline Juva 30 & 4 & 10 & 86 & 100 & 9 & 430 \\
\hline Juva 60 & 3 & 20 & 77 & 93 & 96 & 610 \\
\hline Juva 90 & 3 & 16 & 81 & 96 & $?$ & $?$ \\
\hline
\end{tabular}

Kenttämittauksissa käytettiin eestiläistä Percometeriä, jonka työnimenä oli kehittäjänsä mukaan Plakk (Plakk, 2008) sekä GTK:ssa kehitettyä johtavuustalikkoa (Puranen 
all., 1999) (kuva 1). Plakilla mittattiin maan sähkönjohtavuus ja dielektrisyys sekä johtavuustalikolla maan sähkönjohtavuus Plakkia suuremmassa tilavuudessa. Dielektrisyys muunnettiin maan vesipitoisuudeksi Sutisen (Sutinen, 1992) kaavojen perusteella. Plakin mittauspiste on maahan työnnettävän noin $30 \mathrm{~mm}$ paksun anturin päässä ja sen mittausavaruus on noin $0,5 \mathrm{dm}^{3}$. Johtavuustalikon mittausavaruus on Plakkiin nähden noin satakertainen. Johtavuustalikon mittaus on vakioelektrodivälinen Wenner maavastusluotaus. Suuremman mittausavaruutensa vuoksi laite ei ollut niin herkkä maassa olleelle ilmatilalle kuin Plakk.
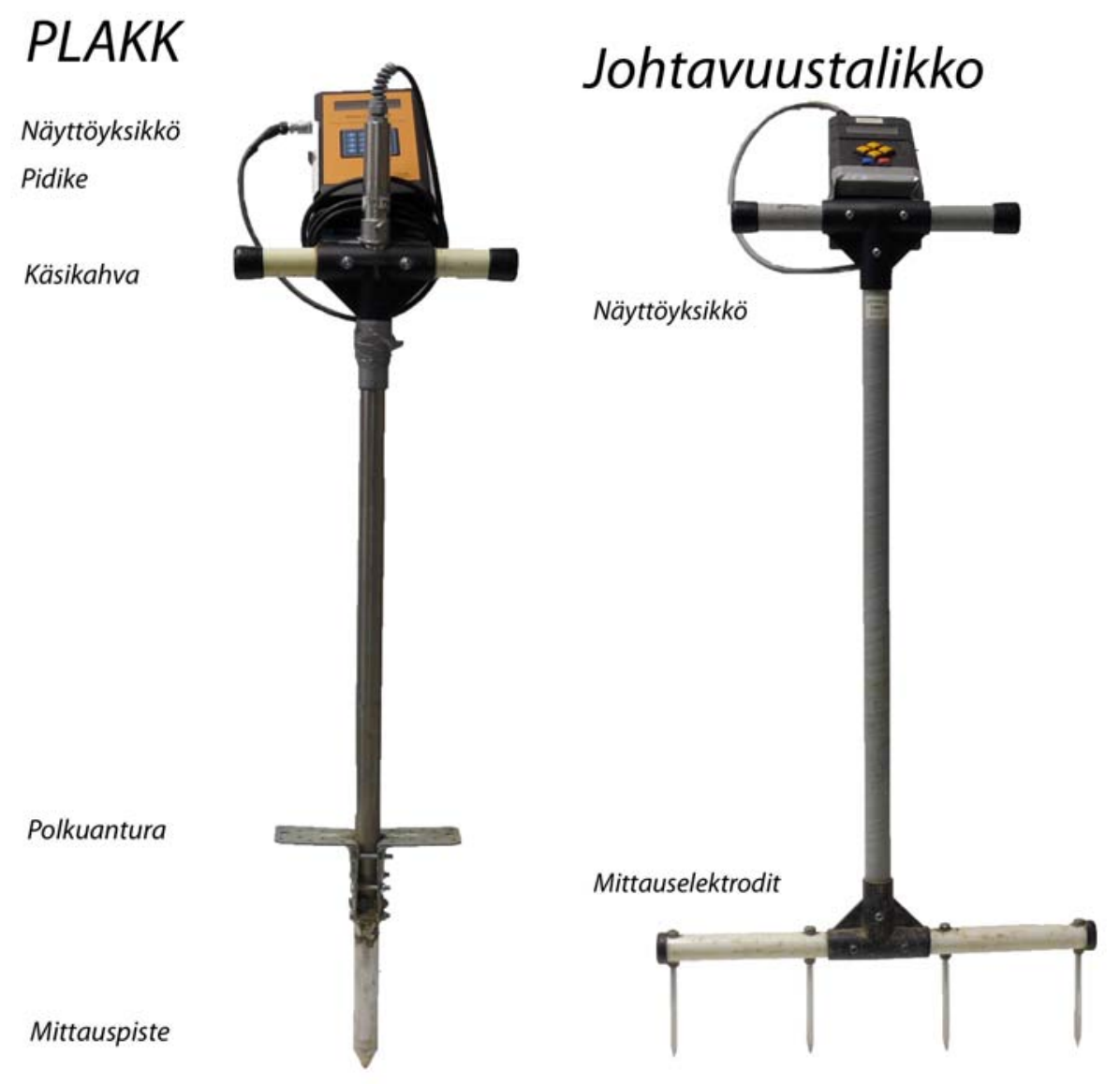

Kuva 1. Pistemäisen dielektrisyyden ja sähkönjohtavuuden mittalaite (Plakk) sekä GTK:n johtavuustalikko, joka mittasi maan keskimääräisen sähkönjohtavuuden muokkauskerroksesta. Käsikahvat ovat noin metrin korkeudella.

Plakilla ja talikolla mitattiin kukin alue kasvukausien aikana useita kertoja. MaSaI:ssä mittauksia tehtiin keväällä, keskikesällä ja syyskesällä. Syyskesän mittaukset todettiin sadon kannalta merkityksettömiksi ja MaSaII:ssa mittaukset tehtiinkin varhaiskeväällä, keväällä ja keskikesällä. Kullekin mittausalueelle merkittiin noin $10 \mathrm{~m}^{*} 10 \mathrm{~m}$ mittausverkko, jotta mittaukset tapahtuisivat aina samoista paikoista.

Seuranta-asemat (kuva 2) perustuivat Campbell Sci dataloggereihin (CR10X) ja niihin liitettyihin kolmeen lämpötila- (T107) ja vesipitoisuusanturiin (CS615/616). Lisäksi asemilla oli maan GTK:ssa johtavuustalikoista maa-asemille kehitetyt sähkönjohtavuusanturit. Mittaukset tapahtuivat pääsääntöisesti kolmen tunnin välein. MaSa hankkeissa käytettiin hyväksi myös GTK:n maaperän seuranta-asemaverkon (Hänninen ym, 2003) Ylistaron (MTT Pelma) asemaa, jolla on mitattu vuodesta 2001 maan lämpötilaa ja kosteutta 10, 30, 50, 70 ja 90 senttimetrin syvyydellä. 


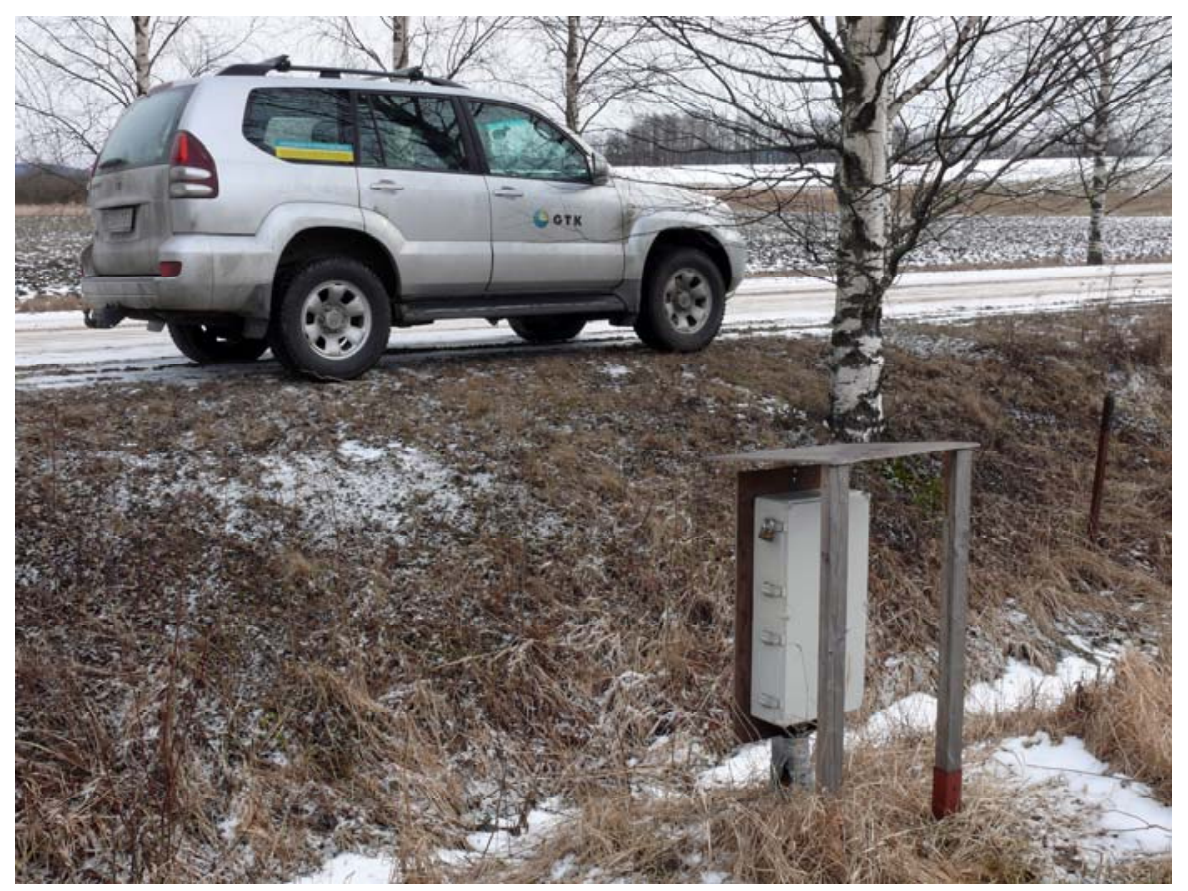

Kuva 2. Vihdin koealueen seuranta-asema. Se mittasi maan kosteuden, sähkönjohtavuuden ja lämpötilan 0,3,0,6 ja 0,9 metrin syvyydessä kolmen tunnin välein..

\section{Tulokset}

Asematuloksista poimittiin kesäaikojen (01.05. -30.09. 2002-05 MaSaI ja 2006-09 MaSaII) seuranta ja määritettiin, kuinka suuria kosteusmuutoksia asemilla tapahtui kahdessa viikossa. Kostuminen laskettiin mittaushetkeä seuraavan kahden viikon suurimman vesipitoisuuden ja mittaushetken kosteuden erotuksesta. Kuivumisessa laskettiin vastaavasti mittaushetken kosteuden erotus sitä seuraavan kahden viikon pienimpään vesipitoisuuteen. Tässä käytetyn algoritmin perusteella ei voida sanoa, tapahtuiko kosteusmuutos kolmessa tunnissa vai kahdessa viikossa. Kerätyn aineiston perusteella sekin on laskettavissa.

Pääsääntöisesti havaitut kosteusmuutokset olivat pieniä (taulukko 2). Vaikka maalajit seurantapisteissä olivat hyvin erilaisia ja niiden laskennalliset veden liikenopeudet sekä vesipitoisuuden mediaanit vaihtelivat suuresti, vesipitoisuusmuutoksien mediaanit olivat hyvin maltillisia vaihdellen välillä $0,3-2,1$ tilavuusprosenttiyksikköä. Vielä yläkvartiilin kohdalla muutokset olivat alle 5 tilavuusprosenttiykikköä, vaikka suurimmat kahdessa viikossa havaitut vesipitoisuusmuutokset olivat yli 23 tilavuusprosenttiyksikköä.

Sateiden vaikutuksen keston todentamiseksi etsittiin eri mittausasemilta yli $20 \mathrm{~mm}$ sadejaksoja ja niitä seuranneita kuivia jaksoja. Näistä tapahtumista määriteltiin, kuinka nopeasti maan kosteus palautui 30 senttimetrin syvyydessä huippuarvostaan alkukosteuteensa. Tähän tutkimusosioon otettiin mukaan myös Pelman seuranta-aseman entiselle savipellolle sijoitettu GTK:n seuranta-asema. Seuranta-asemien mittaustulosten perusteella sateen vaikutus kesti 11-14 vuorokautta. Tulosten mukaan maalaji ei vaikuttanut merkittävästi maaperässä havaittuun sateen vaikutuksen kestoon. Yli $20 \mathrm{~mm}$ sateiden aiheuttamat vesipitoisuusmuutokset havaittiin eri syvyyksillä ja eri maalajeilla mittaustarkkuuden puitteissa yleensä heti tai pienellä, alle vuorokauden, viiveellä.

Koska pysyviä antureita ei voitu asentaa muokkauskerrokseen, ylimmät anturit asennettiin noin $30 \mathrm{~cm}$ syvyyteen. Kenttämittauksissa käytetyn kosteus/sähkönjohtavuus Percometerin (Plakk) mittaussyvyys oli kuivissa olosuhteissa vain 10-20 cm syvyydelle. Siksi kenttämittausten ja aseman tietojen välillä oli syvyyssuunnassa olevista maan kosteuseroista johtuva poikkeama. Poikkeaman selvittämiseksi käytimme hyväksemme GTK:n Ylistaron (MTT Pelma) aseman maankosteustietoja $10 \mathrm{~cm}$ ja $30 \mathrm{~cm}$ syvyydeltä. Vuosien 2001-06 
seurannan perusteella Vihdin lohkon maalajin kaltaisen savikkoalueen maa kuivui toukokuun alusta kesäkuun loppuun $10 \mathrm{~cm}$ syvyydessä noin 10 tilavuusprosenttiyksikköä enemmän kuin $30 \mathrm{~cm}$ syvyydessä.

Taulukko 2. Seuranta-asemilla kesäaikoina (01.05-30.09, vv 2002-05 MaSaI ja 2006-09 MaSaII) havaitut mediaanikosteudet (tilavuusprosenttia) ja kahden viikon aikana havaitut kosteusmuutoksien mediaani ja yläkvartiili. Kostumisen ja kuivumisen luvut ovat tilavuusprosenttiyksikköä.

\begin{tabular}{|l|c|c|c|c|c|}
\hline $\begin{array}{l}\text { Mittaussyvyys } \\
(\mathrm{cm})\end{array}$ & $\begin{array}{l}\text { Vesipitoisuus } \\
\text { mediaani }\end{array}$ & $\begin{array}{c}\text { Kostuminen } \\
\text { mediaani }\end{array}$ & $\begin{array}{c}\text { Kuivuminen } \\
\text { mediaani }\end{array}$ & $\begin{array}{c}\text { Kostuminen } \\
\text { yläkvartiili }\end{array}$ & $\begin{array}{c}\text { Kuivuminen } \\
\text { yläkvartiili }\end{array}$ \\
\hline Hausjärvi 30 & 33 & 1,9 & 2,1 & 4,5 & 4,6 \\
\hline Hausjärvi 60 & 31 & 1,2 & 1,5 & 3,9 & 3,5 \\
\hline Hausjärvi 90 & 29 & 0,3 & 0,3 & 0,8 & 1,1 \\
\hline Jokioinen 30 & 36 & 1,6 & 1,3 & 4,3 & 4,9 \\
\hline Jokioinen 60 & 44 & 0,9 & 0,3 & 2,8 & 4,4 \\
\hline Jokioinen 90 & 46 & 0,5 & 0,9 & 1,7 & 1,1 \\
\hline Vihti 30 & 37 & 1,5 & 1,0 & 3,1 & 2,3 \\
\hline Vihti 60 & 32 & 1,0 & 0,8 & 3,1 & 2,2 \\
\hline Vihti 90 & 51 & 1,4 & 0,7 & 2,5 & 1,3 \\
\hline Juva 30 & 13 & 0,8 & 0,9 & 2,4 & 1,5 \\
\hline Juva 60 & 20 & 1,0 & 1,4 & 2,8 & 2,3 \\
\hline Juva 90 & 30 & 0,8 & 1,3 & 2,5 & 2,2 \\
\hline
\end{tabular}

Vihdin koealueella tehtiin vuoden 2007 kevään ensimmäinen maastomittaus huhtikuun 24. päivänä (kuva 3). Mittaus oli alkutieto mallille, joka laski asemaseurannan perusteella päivittäin uuden maaperän vesipitoisuusjakauman koealueelle. Plakk mittaus vedellä kyllästyneestä maasta ei ollut luotettava ja mitatut lukemat olivat liian suuria. Tämän vuoksi yli 55 tilavuusprosenttiset kosteudet muutettiin 55 tilavuusprosenttiin, mikä oli laboratorionäytteissä suurin havaittu maan pintaosan vesipitoisuus ko. pellolla. Jatkokäsittelyssä yhdenkään kartan verkkopisteen arvoksi ei hyväksytty yli 55 tilavuusprosenttia.

Alkutilanteen perusteella kullekin verkkopisteelle laskettiin uusi päiväkohtainen maankosteuspitoisuus, siten, että alkukosteutta muutettiin suhteessa kiinteällä seurantaasemalla havaittuun kosteusmuutokseen. Ylistaron aseman tulosten perusteella huomioitiin kenttämittaussyvyyden ja seuranta aseman ylimmän kosteuspitoisuuden välin poikkeama vähentämällä pinnasta 01.05 . alkaen 1/60 tilavuusprosenttiyksikköä vuorokautta kohden. Laskennallista karttaa verrattiin kesäkuun 25. päivän kenttämittaustulosten perusteella interpoloituun maan vesipitoisuuskarttaan. Kenttämittausten perusteella ineterpoloidusta maan kosteusjakaumasta vähennettiin laskennallinen mittaustulos ja jäännösverkko piirrettiin kartaksi (kuva 4). Kun käytännön mittaustarkkuudeksi tällä pellolla tiedettiin \pm 2 tilavuusprosenttiyksikköä, hieman alle puolessa pisteitä ennuste toimi tarkasti. Karttatuloksessa näkyi mittausryhmien kädenjälki osoittaen, että mittausrutiineissa on vielä kehittämistä.

Samaa mallia sovitettiin myös Juvan moreenipellolle. Juvan alueella ei tehty kentällä mitatun ja mittausaseman ylimmän kosteusanturin syvyys erosta johtuvaa korjausta. Juvalla maan vedenpidätyskyky on alhainen eikä siellä voinut käyttää savimaalle laskettua korjausta. Juvalla lopputuloksen absoluuttiset virheet olivat selvästi pienempiä kuin Vihdin lohkolla johtuen Juvan koealueen maaperän pienemmistä absoluuttisista vesipitoisuuksista. 


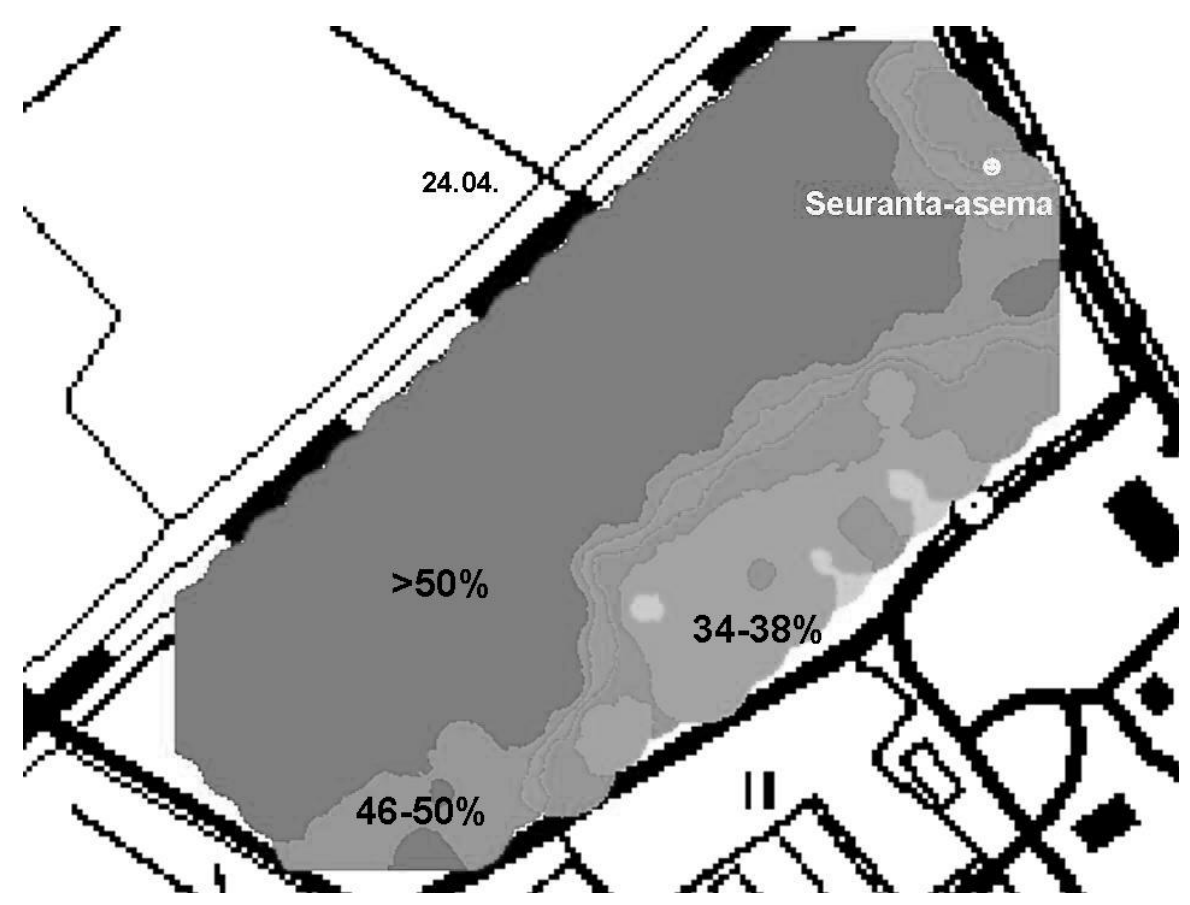

Kuva 3. Vihdin tutkimusalueen kenttämittaustuloksen perusteella interpoloitu maan vesipitoisuus 10-20 cm:n syvyydessä huhtikuun 24. päivänä vuonna 2007. Prosenttiluvut ovat tilavuusprosenttia. Tumman alueella kosteus on yli 50 tilavuusprosenttiyksikköä. Harmaasävyt vaalenevat 4 tilavuusprosentin välein eli kuivimpien alueiden maan kosteudet ovat 30-34 tilavuusprosenttia.

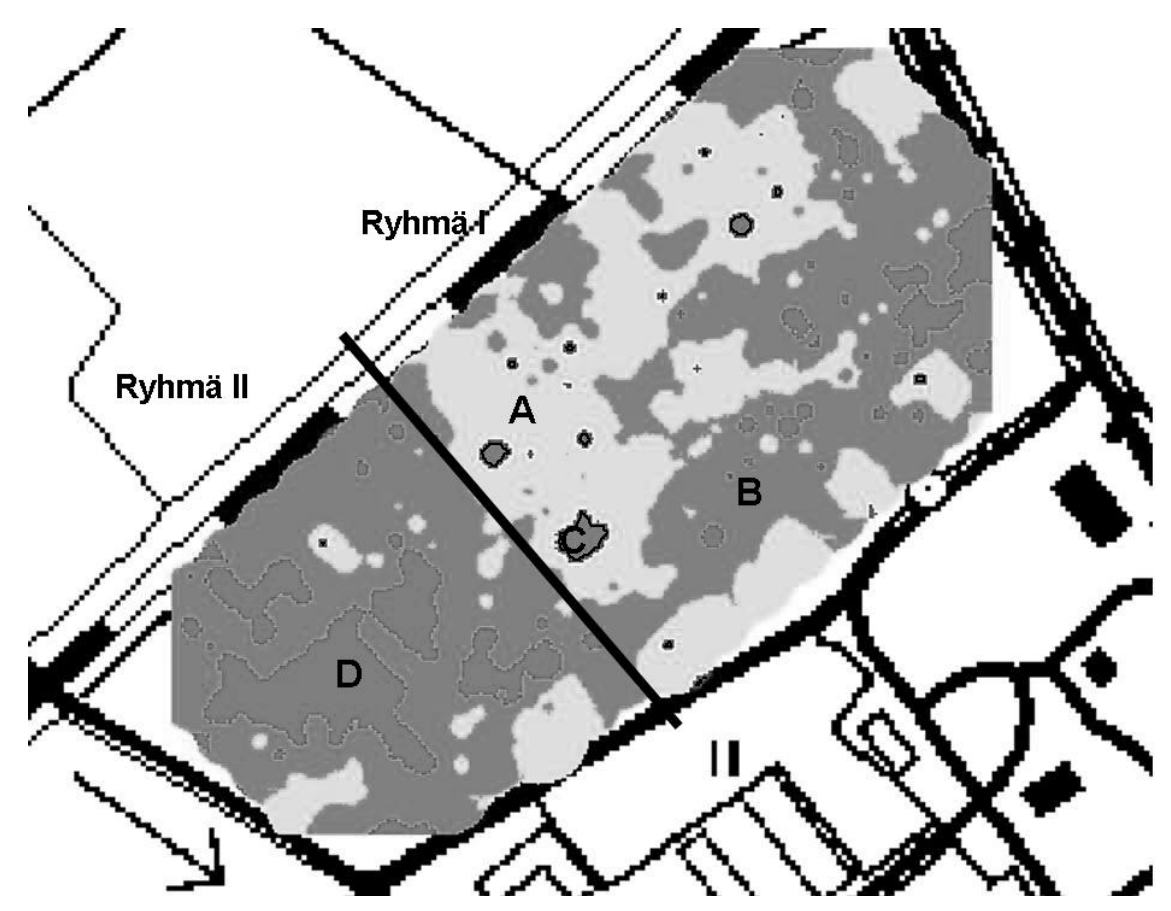

Kuva 4. Vihdin koealueella 25.06.07 mitatun ja 26.04.07 mittaustuloksen ja asemaseurannan perusteella lasketun maan vesipitoisuuden erotus. Vaalealla alueella (A) tulokset ovat mittaustarkkuuden (2 tilavuusprosenttiyksikköä) rajoissa yhtenevät. B-alueella virhe on 2-5 tilavuusprosenttiyksikköä positiivinen ja $\mathrm{C}$-alueella negatiivinen. D-alueella mittaustulos on yli 5 tilavuusprosenttiyksikköä suurempi kuin laskennallinen tulos. 


\section{Johtopäätökset}

Uudet anturi-, mittaus-, kuvaus- ja tiedonkeruutekniikat mahdollistavat peltoalueen lämpötilan ja kosteuden taloudellisesti tehokkaan ja reaaliaikaisen mallintamisen. Mallinnustulos kertoo, onko jossain osassa peltoaluetta odotettavissa kuivuus- tai kosteusongelmia määrätyillä ilmasto-olettamuksilla tai ovatko ongelmat jatkuneet pitkään. Mallinnustulos ei suoranaisesti kerro sadon jakautumisesta peltoalueen eri osissa. Peltoalueen vastaavanlaisen pistekohtaisen tuloksen saaminen perustuen maalajiin, kasvillisuuteen, ilmastotekijöihin jne. tarvitsee suuren määrän stabiileja ja aikaan sidottuja muuttujia ja muuttujahistoriaa. Valitettavasti se viimeinen tekijä, eli miten tilanne mallintamishetkestä eteenpäin kehittyy, on ratkaisematta.

Tulosten perusteella peltoalue voidaan luokitella savisiin, hienoihin ja karkeisiin maaalueisiin sähköisten dielektrisyys ja johtavuusmittausten avulla. Jatkuvatoimisten seurantaasemien mittausten perusteella ruokamultakerroksen alapuolella maan kosteuden muutokset olivat suhteellisen pieniä. Kasvukaudella $75 \%$ kahden viikon aikana tapahtuneista maan kosteuden muutoksista oli pienempiä kuin 5 tilavuusprosenttiyksikköä. Voimakkaiden sateiden jälkeen pelloissa voi kuitenkin tapahtua nopeasti suuria kosteuspitoisuuden muutoksia.

Kenttämittausten perusteella maan kosteuden muutokset olivat spatiaalisesti pysyviä ja siten hallittavia yhden seuranta-aseman tulosten perusteella. Tutkimuksessa luotiin yksinkertainen malli, jossa jatkuvasti mittaavan seuranta-aseman ja keväällä tehdyn kertamittauksen perusteella kuvattiin kasvukauden aikana päivittäin peltoalueen vesitilaa ja sen muutosta. Maan kosteuden lohkomittakaavainen ennustaminen paranee, jos tekniikan kehittyessä voidaan taloudellisesti saada luokitellulle alueelle kiinteä seuranta-asemaverkosto.

Seurattujen makerrosten pääsääntöisesti lähes yhtaikaiset vesipitoisuusmuutokset osoittavat, että peltomaan veden liike riippuu pikemminkin oikovirtausreiteistä kuin maan materiaaliominaisuuksista.

\section{Kirjallisuus}

Hänninen. P., Sutinen, R., Suomi, T., Äikää, O., Penttinen, S. \& Majaniemi., J. 2003. GTK:n maaperän seuranta-asemat 2000-2002. Geologian tutkimuskeskus, Raportti P31.4.035. 21 s.

Plakk, T. 2008. Percometer - a capacitive probe instrument for soil dielectric constant and conductivity measurement and monitoring. International Conference on Metrology of Environmental, Food and Nutritional Measurements.,9.-12.09.2008, Budapest, Hungary. S. 17-19.

Plakk, T. 1994. HF Permittivity measurements by capacitive probe. Unpublished article. Adek Ltd, Estonia

Puranen, R., Sulkanen, K., Nissinen, R. \& Simelius, P. 1999. Ominaisvastusluotaimet ja vastustalikot. Geologian tutkimuskeskus, Raportti Q15/27.4/99/2. 8 s. + 1 liite.

Ristolainen, A., Jaakkola, A., Hänninen, P. \& Alakukku, L. 2006. Sadon ja maan ominaisuuksien vaihtelun käyttö suunnittelussa .Laura Alakukku (toim.). Maaperän prosessit - pellon kunnon ja ympäristönhoidon perusta : MMM:n maaperätutkimusohjelman loppuraportti. Maa- ja elintarviketalous 82: s. 82-92.

Ristolainen, A., Hänninen, P., Hakojärvi, M., Mannfors, B. \& Alakukku, L. 2009. MaSa raportti Maaperäfysiikka ja sato - Hiesu- ja moreenimaiden sähköiset ominaisuudet ja niiden monitorointi, Masa2 (2006-2009). 22 p. (Loppuraportti elokuu 2009)

Sutinen, R. 1992. Glacial deposits, their electrical properties and surveying by image interpretation and ground penetrating radar, Geological survey of Finland, Bulletin 359. 123 p.

Sutinen, R., Middleton, M., Hänninen, P., Varitainen, S., Venäläinen, A. Sutinen, M-L, 2007. Dielectric constant time stability of glacial till at clear-cut site. Geoderma, Vol. 141, s. 311-319.

Vukovic M. \& Soro A. 1992. Determination of hydraulic conductivity of porous media from grainsize composition. Water Resources Publications, USA. 83 p. 